\title{
DEVELOPMENT OF A DIDACTIC WORKBENCH USING REAL-TIME MONITORING SYSTEM FOR TEACHING OF PHOTOVOLTAIC SYSTEMS
}

\author{
Sérgio A. Oliveira da Silva, Danilo H. Wollz, Leonardo P. Sampaio \\ Federal University of Technology - UTFPR-CP, Department of Electrical Engineering, Cornélio Procópio - PR - Brazil \\ e-mail: augus@utfpr.edu.br,danilo_wollz@hotmail.com, sampaio@utfpr.edu.br
}

\begin{abstract}
This paper presents the deployment of a didactic workbench intended to support theoretical and practical studies addressed in subjects of undergraduate and postgraduate electrical engineering courses involving photovoltaic (PV) systems. The proposed system operates in real-time and is composed of a computational graphic interface operating in conjunction with a double-stage PV system connected to the power grid. Besides the PV array, the PV system consists of a step-up DC-DC converter, intended to track the maximum power point, and a current-controlled full-bridge inverter, intended to inject the energy produced by the PV array into the grid. The monitoring system allows to perform the following tasks: i. assist the performance evaluation of maximum power point tracking techniques tied to projects; ii. visualize the measured PV array magnitudes (voltage, current and power), as well as the estimated ones calculated from the PV array mathematical model and from the real measured values of solar irradiation and temperature; iii. analyze electric power quality indicators, based on the grid voltage and current magnitudes, and others. Experimental results are presented with the objective of testing and evaluating the versatility of the proposed didactic workbench applied in an educational environment.
\end{abstract}

Keywords - Didactic Workbench, Educational PV System, Graphical User Interface, Real-time Monitoring.

\section{INTRODUCTION}

In the last few decades, the use of alternative energy sources based on renewable energy sources (RES) has been increasing due to the growing demand for electricity, as well as the real need to replace non-renewable energy sources based on fossil fuels, which carry the disadvantage of causing considerable environmental impacts [1], [2]. Within this context, solar energy [1]-[3] and wind energy [4], [5] have been consolidated as the main RES used for electricity generation. Among the various forms of electric energy production from solar energy, photovoltaic (PV) panels have been widely used and diffused in distributed generation systems [6], [7].

Considering an educational environment, several topics and/or subjects that are being discussed and taught in undergraduate and postgraduate electrical engineering courses are linked to some technological applications involving RES, in particular to PV systems, for instance [8]-[12].

Thus, inserted in a teaching context, discussions about PV systems supported by computational tools can stablish more dynamic and accessible interaction with students, as well as can accelerate the teaching-learning process [13]-[16]. Furthermore, theoretical concepts can be more easily assimilated and consolidated, as well as the development of engineering activities tied to projects can be optimized and/or validated [17], [18].

The main contribution of this paper is the deployment of a didactic workbench intended to support theoretical and practical studies addressed in subjects of undergraduate and postgraduate electrical engineering courses involving PV systems. The proposed system integrates a real-time monitoring system (RTMS) with a PV system connected to the power grid resulting in a versatile teaching platform.

The referred educational tool can perform the following tasks: 1) assist the performance evaluation of maximum power point tracking (MPPT) techniques tied to projects; 2) validate the PV cell modeling and estimate parameters of the PV array; 3 ) detect the power generated by the PV array and the power injected into the grid; 4) evaluate power quality indicators, such as power factor (PF) and total harmonic distortion (THD) involving the current injected into the grid; 5) visualize, in real-time, quantities of voltage and current, trace the PV array characteristic curves $\left(I_{P V} x V_{P V}\right.$ and $\left.P_{P V} x V_{P V}\right)$, and others.

The interaction between the RTMS and the student is achieved through a graphical user interface (GUI), which can help the development the mentioned tasks [13], [19].

Furthermore, once the educational platform developed is conceived by means the use of static converters, such as the step-up DC-DC converter (quadratic boost converter) and the single-phase full-bridge voltage-source inverter (VSI), some subjects related to power electronics concepts can also be widely explored, especially those related to the control system and design and modelling of static converters [20].

This paper is organized as follows: Section 2 presents the PV system characteristics involving the PV cell model, the power converters control systems and the MPPT technique. The PV system integrated to the didactic workbench is described in Section 3. Experimental results are shown in Section 4 to evaluate the versatility of the graphical user interface and the real-time monitoring system. The application of the didactic workbench for educational purposes is shown in Section 5. Section 6 presents the conclusions. 


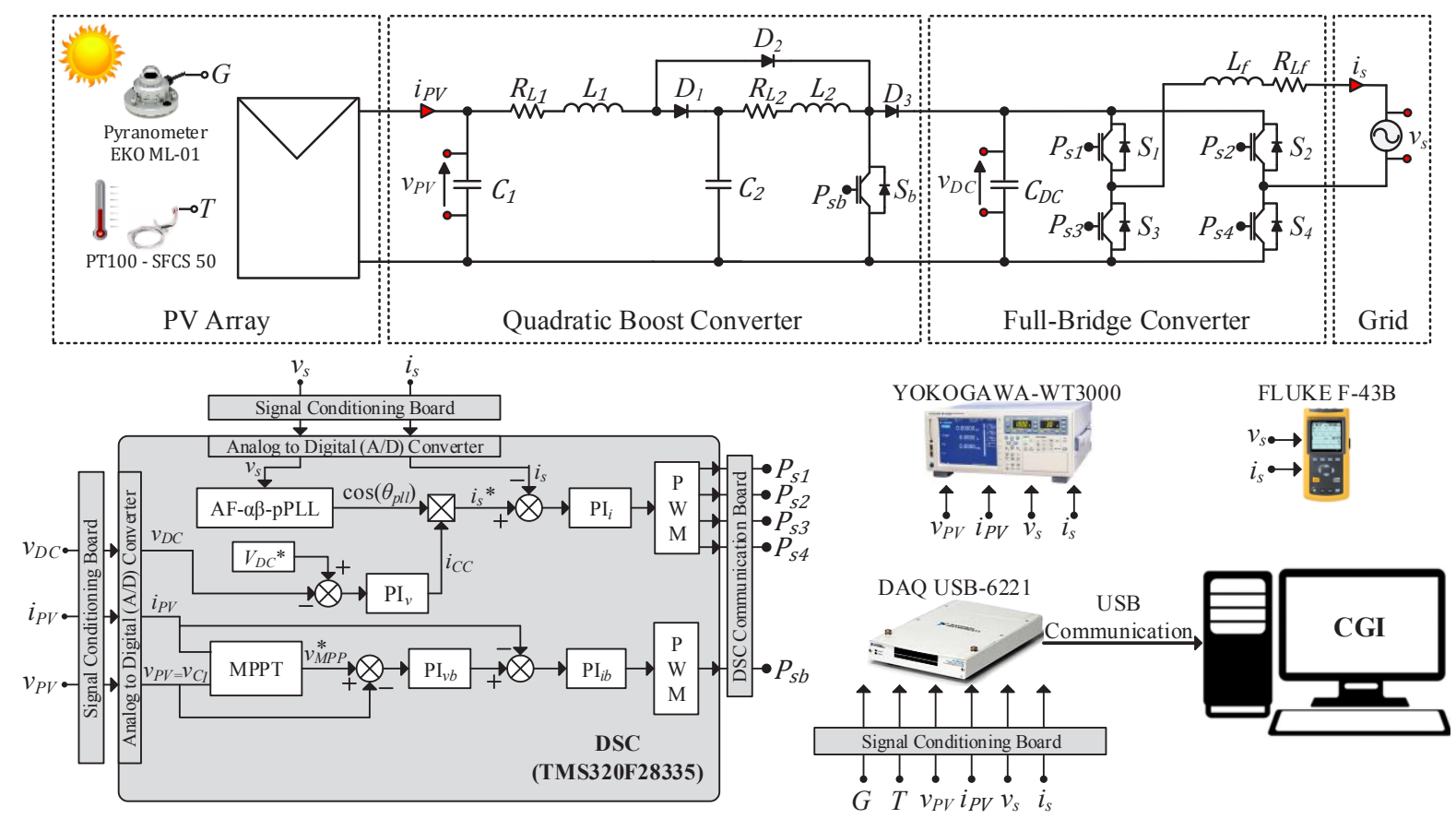

Fig. 1. Complete scheme of the real-time monitoring system (RTMS).

\section{DESCRIPTION OF THE DIDACTIC WORKBENCH}

The comprehensive scheme of the proposed didactic workbench is shown in Figure 1. It comprises a PV panel, a DC-DC quadratic boost converter followed by a single-phase full-bridge VSI. The experimental set uses a DSC (Digital Signal Controller), where the MPPT technique, the phaselocked loop (PLL) scheme, and the control loops of the inverter and the DC-DC converter are embedded. The data acquisition system DAQ USB-6222 (National Instruments) is responsible for acquiring the system signals (PV system and grid quantities, solar irradiation and temperature) and to perform the communication between USB and RTMS. In addition, LabVIEW software (National Instruments) is employed to operate integrated with the hardware (DAQ) and visualize all the aspects of the application by means of a graphical programming.

Since the GUI was developed based on this platform, it is possible to visualize, for example, the characteristic curves of the PV array, such as current-voltage $\left(I_{P V} \mathrm{x} V_{P V}\right)$ and powervoltage $\left(P_{P V} \mathrm{x} V_{P V}\right)$, which are traced using the mathematical model of the PV cell and the measured signals as solar irradiation and temperature. Furthermore, the voltage and current at the PV array terminals, the power drained from the PV panel, the grid voltage and the current injected into the grid can also be viewed. As a result, the performance of the adopted MPPT technique can be evaluated, allowing to check if the system is extracting the maximum power the PV array is able of generating.

\section{DESCRIPTION OF THE PV SYSTEM}

In this section is described the model that represents the PV cell, as well as the power circuits that compose the PV system integrated to the didactic workbench.

\section{A. PV Cell Mathematical Model}

The equivalent electric circuit that represents the model of a PV cell adopted in this paper is presented to carry out the study and implementation of the PV system. The PV cell mathematical model is used to create the PV array characteristic curves $I_{P V} \times V_{P V}$ and $P_{P V} \times V_{P V}$ from the information obtained by means of the solar irradiation and temperature. Therefore, it is possible to check if the actual values of the monitored quantities of the PV array, including voltage $V_{P V}$, current $I_{P V}$ and power $P_{P V}$, correspond to the values estimated and obtained from the model.

The equivalent electric of the PV cell circuit adopted in this paper is shown in Figure 2 [21]-[23], where $I_{p h}$ is the photocurrent; I represents the output current of the PV cell; $V$ is the output voltage of the cell. In addition, the series and parallel resistances are represented by $R_{s}$ and $R_{p}$, respectively.

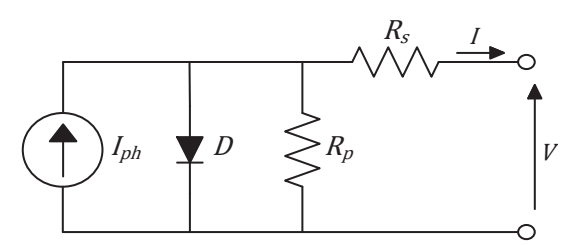

Fig. 2. Equivalent circuit of the photovoltaic cell.

The magnitudes $I$ and $I_{p h}$, the reverse saturation current $I_{r}$, the reverse saturation current $\left(I_{r(S T C)}\right)$ in STC (Standard Test Conditions), the PV module voltage $\left(V_{P V}\right)$ and the open circuit voltage of the photovoltaic array $\left(V_{O C}\right)$ can be identified by (1), (2), (3), (4), (5) and (6) [22], respectively, where $q$ is the electron charge; $\eta$ is the ideality factor of the $\mathrm{p}-\mathrm{n}$ junction; $k$ is the Boltzmann's constant; $T_{r}$ is the nominal temperature in Kelvin; $I_{S C}$ is the short-circuit current in STC $\left(T_{r}=298 \mathrm{~K}\right.$ and $\left.\mathrm{G}=1000 \mathrm{~W} / \mathrm{m}^{2}\right) ; \alpha$ is the temperature coefficient; $E_{g}$ is the band energy $(1.1 \mathrm{eV}) ; V_{O C_{-} c}$ is the open circuit voltage of the photovoltaic cell; and $N_{s}$ is the number of photovoltaic cells. 


$$
\begin{gathered}
I=I_{p h}-I_{r}\left[e^{q \frac{V+I R_{S}}{\eta k T}}-1\right]-\frac{V+I R_{s}}{R_{p}} \\
I_{p h}=\left[I_{S C}+\alpha\left(T-T_{r}\right)\right] \frac{G}{1000} \\
I_{r}=I_{r(S T C)}\left(\frac{T}{T_{r}}\right)^{3} e^{\left[\frac{q E_{g}}{\eta k}\left(\frac{1}{T_{r}}-\frac{1}{T}\right)\right]} \\
I_{r(S T C)}=\frac{I_{S C}-\frac{V}{R_{p}}}{e^{\frac{q V_{O C_{-} c}}{\eta k T_{r}}}-1} \\
V_{P V}=V N_{S} \\
V_{O C}=V_{O C_{-} c} N_{S}
\end{gathered}
$$

To solve the set of equations from (1) to (6), a numerical method was used. For that reason, the current of the cell for a given operation point is obtained by adopting the NewtonRaphson method represented by (7), where $n$ is the nth iteration of the algorithm and $f^{\prime}\left(I_{n}\right)$ is the derivative of the current corresponding to iteration $n$. Thus, (8) and (9) determine the current of the PV cell for a given iteration.

$$
\begin{gathered}
I_{n+1}=I_{n}-\frac{f\left(I_{n}\right)}{f^{\prime}\left(I_{n}\right)} \\
f\left(I_{n}\right)=I_{p h}-I_{n}-I_{r}\left[e^{q \frac{V+I_{n} R_{s}}{\eta k T}}-1\right]-\frac{V+I_{n} R_{s}}{R_{p}} \\
f^{\prime}\left(I_{n}\right)=-1-I_{r} e^{q \frac{V+I_{n} R_{s}}{\eta k T}} \frac{q I_{n} R_{s}}{\eta k T}-\frac{R_{s}}{R_{p}}
\end{gathered}
$$

Known the PV mathematical model and considering the PV parameters, the characteristic curves $I_{P V} \times V_{P V}$ and $P_{P V} \times V_{P V}$ can be obtained, as shown in Figures $3 \mathrm{a}$ and $3 \mathrm{~b}$, respectively.

Table I presents the parameters used in the mathematical model of the PV cell, such as $q, k, \alpha, E_{g}, \eta, R_{s}$ and $R_{p}$. Additional PV parameters, such as the maximum power of the PV array $P_{\max }=P_{M P P}$, voltage $V_{M P P}$ and current $I_{M P P}$ at the maximum power point, open circuit voltage $V_{O C}$, short circuit current $I_{S C}$, number of cells $N_{s}$ and current temperature coefficient $\alpha$ were extracted from de PV manufacturer data (PV module SW245 - SolarWorld).

As can be noted in Figures $3 \mathrm{c}$ and $3 \mathrm{~d}$, according to the variations of solar irradiation and temperature, the maximum power point $\left(P_{M P P}\right)$ varies, too.

\section{TABLE I}

Parameters of the SolarWorld PV SW 245 Panel under Standard Test Conditions (STC)

\begin{tabular}{cc}
\hline Maximum power of the PV array & $P_{\max }=P_{M P P}=245 \mathrm{~W}$ \\
\hline Voltage in the maximum power point & $V_{M P P}=30.8 \mathrm{~V}$ \\
\hline Current in the maximum power point & $I_{M P P}=7.96 \mathrm{~A}$ \\
\hline Open circuit voltage & $V_{O C}=37.5 \mathrm{~V}$ \\
\hline Short circuit current & $I_{S C}=8.49 \mathrm{~A}$ \\
\hline Number of cells & $N_{s}=60$ \\
\hline Electron charge & $q=1.6 \times 10^{-19} \mathrm{C}$ \\
\hline Boltzmann constant & $k=1.38 \times 10^{-23} \mathrm{~J} / \mathrm{K}$ \\
\hline Current temperature coefficient & $\alpha=6 \mathrm{~mA} / \mathrm{K}$ \\
\hline Silicon band energy gap & $E_{g}=1.1 \mathrm{eV}$ \\
\hline Adopted p-n junction ideality factor & $\eta=1.2$ \\
\hline Series resistance (Figure 2) & $R_{s}=3.08 \mathrm{~m} \Omega$ \\
\hline Parallel resistance (Figure 2) & $R_{p}=15.38 \Omega$ \\
\hline
\end{tabular}

\section{B. DC-AC Full-bridge Converter}

The single-phase full-bridge VSI is used to connect the PV system to the grid as shown in Figure 1, while its equivalent circuit is shown in Figure 4, where $v_{s}$ is the mains voltage; $v_{D C}$ is the DC-bus voltage; $d$ is the duty cycle of the PWM inverter; and $L_{f}$ and $R_{L f}$ represent the inductance and internal resistance of the filtering inductor, respectively.

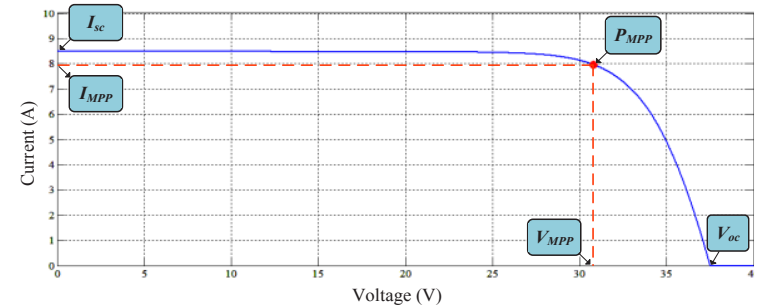

(a)

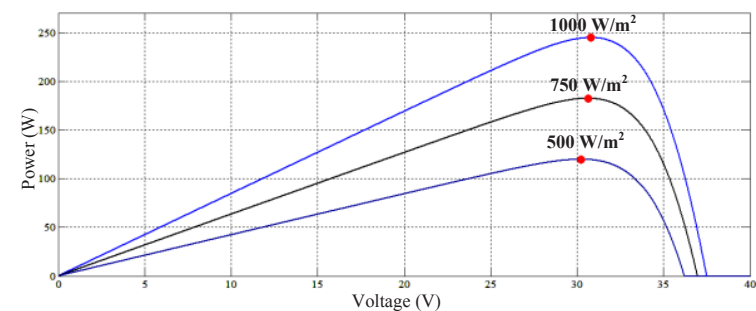

(c)

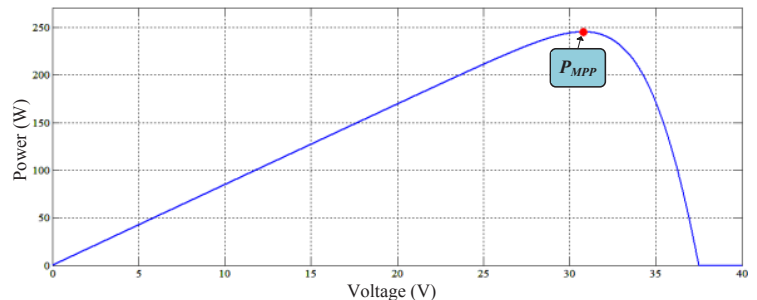

(b)

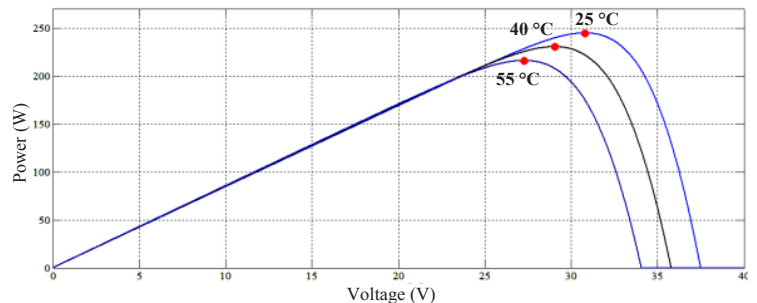

(d)

Fig. 3. PV array curves: (a) characteristic curve $I_{P V} \times V_{P V}$, (b) characteristic curve $P_{P V} \times V_{P V}$, (c) $P_{P V} \times V_{P V}$ curve with solar irradiation variation, (d) $\mathrm{P}_{\mathrm{PV}} \times \mathrm{V}_{\mathrm{PV}}$ curve with temperature variation. 
The full-bridge inverter topology was chosen due to the possibility to employ the pulse width modulation (PWM) with a unipolar (three-level) voltage switching. This PWM technique has advantage when compared to the PWM with bipolar voltage switching, because it effectively doubling the switching frequency that appears in the harmonic spectrum of the output inverter voltage waveform. On the other hand, fullbridge inverter topology driven by unipolar voltage switching results in the increase of PV array common-mode current due to the variations of the common-mode voltage of the fullbridge inverter [24].

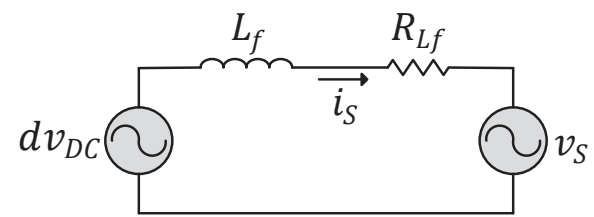

Fig. 4. DC-AC full-bridge converter: equivalent electric circuit of the grid-tied inverter

Applying the small-signal modeling [20] and neglecting the disturbances in the grid voltage and in the DC-bus, the transfer function that relates the input current $\left(i_{s}\right)$ and the duty cycle $(d)$ of the PWM inverter can be found as:

$$
G_{i_{s} d}(s)=\frac{\hat{\imath}_{s}(s)}{\hat{d}(s)}=\frac{V_{D C}}{L_{f} s+R_{L f}} .
$$

Figure 5 presents the control system block diagram of the inverter current and the DC-bus voltage, where $K_{P i}$ and $K_{I i}$ represent the proportional-integrative (PI) gains of the current controller; $K_{P v}$ and $K_{I v}$ are the PI gains of the DC-bus voltage controller; and $K_{P W M}$ represents the static gain of the pulse width modulator, which is calculated considering the inverse of the peak value of the triangular carrier [20].

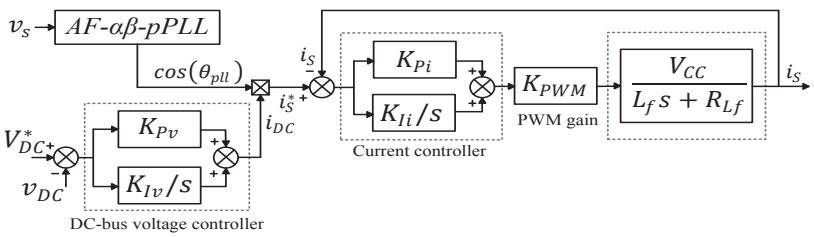

Fig. 5. DC-AC full-bridge converter: control system block diagram of the inverter current and the DC-bus voltage.
The DC-bus PI controller output signal, defined by $i_{D C}$ maintains the DC-bus voltage constant, as well as to control the amplitude of the current $i_{s}$ injected into the grid [25], while a single-phase PLL system is used to obtain the sinusoidal reference current $\left(i_{s}^{*}\right)$ of the current controller synchronized with the grid voltage [26].

\section{Quadratic Boost Converter}

The use of the quadratic boost converter is justified due to the need to obtain a high voltage gain in the converter $\left(G_{b_{-} q} \cong\right.$ $7)$, since the voltage of a single PV panel in MPPT $\left(V_{M P P} \cong\right.$ $30.8 \mathrm{~V}$ ) must be increased to $V_{D C}=220 \mathrm{~V}$ (DC-bus inverter). The quadratic boost converter is also controlled to track the maximum point of power of the PV array, to follow the voltage reference provided by the MPPT algorithm.

From the circuit shown in Figure $6 \mathrm{a}$, the model of the quadratic boost converter working to reach the MPPT can be obtained, where $R_{\mathrm{PV}}$ is the output impedance of the PV array in STC $\left(\mathrm{G}=1000 \mathrm{~W} / \mathrm{m}^{2}\right.$ and $\left.\mathrm{T}=25^{\circ} \mathrm{C}\right) ; C_{1}$ and $C_{2}$ are the filter capacitances; $L_{1}$ and $L_{2}$ are the filter inductances of the converter, while $R_{L 1}$ and $R_{L 2}$ are their respective internal resistances. The output voltage of the converter is considered constant, since it is controlled by the DC-bus voltage controller shown in Figure 5. The equivalent circuits representing the operating stages of the DC-DC converter are shown Figure $6 \mathrm{~b}\left(S_{b}\right.$ switch turned on), and Figure 6c $\left(S_{b}\right.$ switch turned off).

Figure $6 \mathrm{~d}$ shows the block diagram of the multi-loop control of the quadratic boost converter, which is composed of an inner current control loop and an outer voltage control loop.

Due to the presence of resonance peaks, caused by the LC filter, the use of a single PI voltage controller can become the closed-loop control system unstable. Thus, to overcome this problem and contribute to attenuate the resonance peaks, it is employed the inner current control loop whose PI controller must be tuned in frequencies higher than the frequencies in which the resonance peaks occur. Therefore, by tuning the outer PI voltage controller in frequencies lower than the resonant ones, it is possible to guarantee the stability of the system.

Through the application of small-signal modeling, the transfer functions of the two control loops of the converter are obtained, namely: the external voltage loop $G_{v b_{i}}(s)$ and the internal current loop $G_{i b_{d}}(s)$, which are respectively given by:

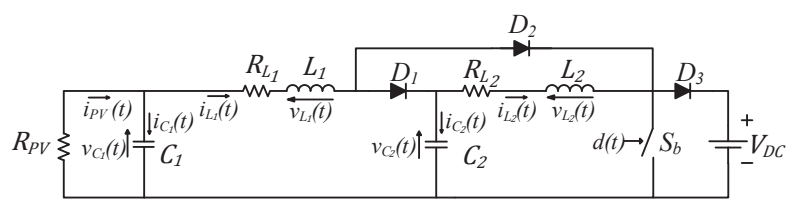

(a)

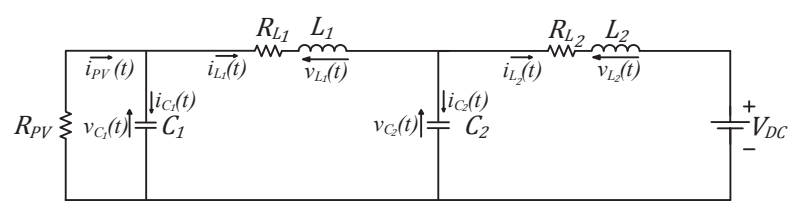

(c)

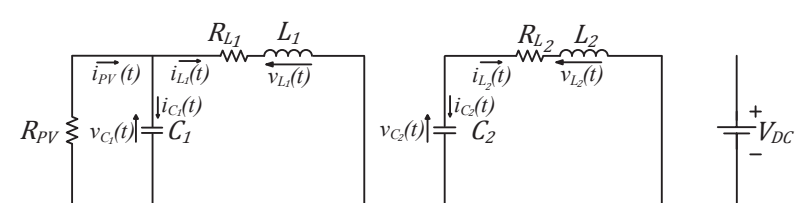

(b)

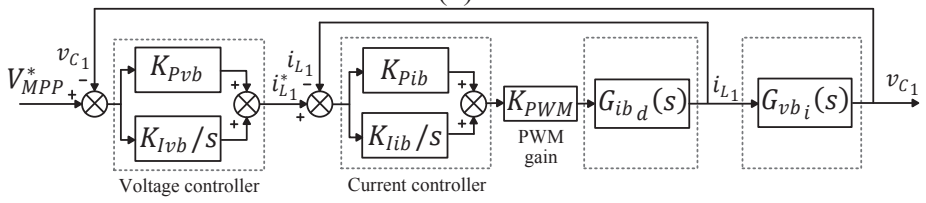

(d)

Fig. 6. Electrical circuit and operating stages of the quadratic boost converter: (a) model of the quadratic boost converter; (b) first operating stage (switch on), (c) second operating stage (switch off), (d) block diagram of the current and voltage control loops. 


$$
\begin{gathered}
G_{v b_{i}}(s)=\frac{\hat{v}_{C_{1}}(s)}{\hat{\imath}_{L_{1}}(s)}=-\frac{R_{P V}}{C_{1} R_{P V} s+1} \\
G_{i b_{d}}(s)=\frac{\hat{\iota}_{L_{1}}(s)}{\hat{d}_{b}(s)}=\frac{a_{0} s^{3}+a_{1} s^{2}+a_{2} s+a_{3}}{b_{0} s^{4}+b_{1} s^{3}+b_{2} s^{2}+b_{3} s+b_{4}}
\end{gathered}
$$

where:

$$
\begin{aligned}
& a_{0}=C_{1} C_{2} L_{2} V_{C_{2}} \text {; } \\
& a_{1}=C_{1} D^{\prime} I_{L 1} L_{2}+C_{1} C_{2} R_{L_{2}} V_{C_{2}}+C_{2} L_{2} R_{P V} V_{C_{2}} \text {; } \\
& a_{2}=C_{1} V_{C_{2}}+C_{1} D^{\prime} V_{c c}+C_{1} D^{\prime} I_{L 1} L_{2} R_{L 2}+D^{\prime} I_{L 1} L_{2} R_{P V} \\
& +C_{2} R_{L_{2}} R_{P V} V_{C_{2}} \\
& a_{3}=R_{P V} V_{C 2}+D^{\prime} R_{P V} V_{c C}+D^{\prime} I_{L 1} R_{L_{2}} R_{P V} \text {; } \\
& b_{0}=C_{1} C_{2} L_{1} L_{2} \\
& b_{1}=C_{1} C_{2} L_{1} R_{L_{2}}+C_{1} C_{2} L_{2} R_{L_{1}}+C_{2} L_{1} L_{2} R_{P V} \\
& b_{2}=C_{1} L_{2} D^{\prime 2}+C_{1} L_{1}+C_{2} L_{2}+C_{1} C_{2} R_{L_{1}} R_{L_{2}} \\
& +C_{2} L_{2} R_{L_{1}} R_{P V} \text {; } \\
& b_{3}=C_{1} R_{L_{1}}+C_{2} R_{L_{2}}+L_{1} R_{P V}+C_{1} D^{\prime 2} R_{L_{2}}+D^{\prime 2} L_{2} R_{P V} \\
& +C_{2} R_{L_{1}} R_{L_{2}} R_{P V} \\
& b_{4}=R_{L_{2}} R_{P V} D^{\prime 2}+R_{L_{1}} R_{P V}+1 \text {. }
\end{aligned}
$$

The quantity $V_{C_{2}}$ represents the specified average voltage in the capacitor $C_{2} ; I_{L 1}$ is the specified average current of the inductor $L_{1}$; and $D^{\prime}=1-D$, where $\mathrm{D}$ is the converter duty cycle

Figure $6 \mathrm{~d}$ shows the input voltage control system $v_{C_{1}}(t)$ of the quadratic boost converter, where the internal current control loop in the inductor $L_{1}$ and the external voltage control loop $\left(C_{1}\right)$ are represented. This loop must ensure that the voltage across the capacitor $C_{1}$ follows the reference set by the MPPT algorithm $\left(V_{M P P}^{*}\right)$. The gains $K_{P v b}$ and $K_{I v b}$ represent, respectively, the proportional and integral gains of the voltage controller, while $K_{P i b}$ and $K_{I i b}$ represent the PI gains of the current control loop.

\section{MPPT Algorithm}

In spite of all the advantages presented by the generation of electric energy by the photovoltaic panel, the efficiency of the conversion of solar energy to electric energy is currently low, and the initial cost for its implementation is still considered high. Therefore, it is necessary to apply the MPPT techniques in order to obtain the best use of electric energy produced by a PV array. Nonetheless, there is only one point of maximum power $\left(P_{M P P}\right)$ to be reached, which varies according to climatic conditions, such as solar irradiation and temperature.

The MPPT based on Perturb and Observe ( $\mathrm{P} \& \mathrm{O})$ technique [1], [27] was adopted in the present paper to achieve the MPP of a PV array that is composed of a unique PV panel. The flowchart of the P\&O-based MPPT is shown in Figure 7.

The time between the changes in the PV panel voltage references obtained from the MPPT based on P\&O algorithm must be necessarily higher than the set-up time of the control system. If this condition is not met, the MPPT algorithm can operate incorrectly, due to the PV array voltage will still be changing at the time in which a new PV voltage reference is set by the MPPT algorithm. Thus, to ensure the PV voltage controller being fast enough, its crossover frequency at $0 \mathrm{~dB}$ was selected at three times higher than the MPPT frequency, as can be observed in Table II $\left(f_{S \_M P P T}=5 \mathrm{~Hz}\right)$ and Table III $\left(\omega_{c v b}=96.66 \mathrm{rad} / \mathrm{s}\right)$.

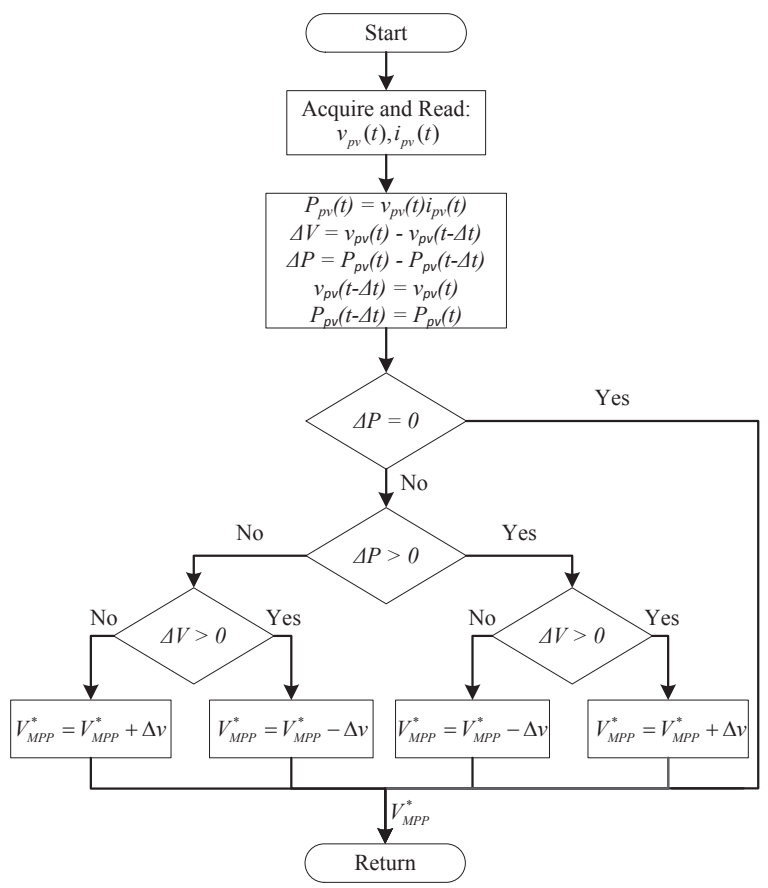

Fig. 7. Flowchart of the MPPT based on P\&O technique.

\section{EXPERIMENTAL RESULTS}

In this section, experimental results are presented with the objective of evaluating the operation of the didactic workbench. (educational platform), based on the scheme shown in Figure 1.

The full-bridge inverter was built using IGBT SK40GB123 (Semikron) power modules, whereas in the quadratic boost converter the discrete IGBT IRGP50B60PD1PBF and diodes HFA30PB120PBF (Vishay) were used. The MPPT and PLL algorithms, as well as the converters control loops were embedded into the digital signal controller TMS320F28335 (Texas Instruments). The LA 55-P and LV 25-P (LEM) transducers were used in measurements of current and voltage quantities, respectively. For sensing the solar irradiation, the pyrometer ML-01 EKO (Eko Instruments) was used, while the temperature of the PV array was measured through the surface temperature sensor PT-100 SFCSD-50 (Kimo Instruments). Finally, monitored signals and communication with the LabVIEW software were acquired by means of a DAQ NI USB-6221 (National Instruments) data acquisition board.

The prototype parameters are listed in Table II, while the design specifications, as well as the gains of the PI controllers (DC/DC a DC/AC converters) are presented in Table III.

As aforementioned, the GUI presented in this paper was developed using LabVIEW software. It is divided in six interactive user interfaces (INT), as shown in Figures 8 and 9.

Figure 8a shows the interface 1 (INT1), called "Settings", where the user must enter the PV array parameters at STC, such as $P_{\max }=P_{M P P}, V_{M P P}, I_{M P P}, V_{O C}, I_{S C}, N_{s}, G$ and $T$, as well as the sampling frequency and sample rate settings of the DAQ NI USB-6221. Additional parameters that compose the PV cell model, such as $q, k, \alpha, E g$, and $\eta$ have been previously stored in the GUI library as default values. 
Interface 2 (INT2), shown in Figure 8b, represents a subinterface of INT1. In this interface, called "Adjustments of series and parallel resistances of the PV cell model", the user can adjust the values of $R_{s}$ and $R_{p}$ that refer to the model of the PV cell shown in Figure 2. This procedure must be performed to meet the specification parameters of the PV module shown in Table I.

It can be noted from INT2 (Figure $8 \mathrm{~b}$ ), after the adjusting $R_{s}=3.08 \mathrm{~m} \Omega$ and $R_{p}=15.38 \Omega$, the values of $P_{M P P}, V_{M P P}, I_{M P P}$, $V_{O C}$, and $I_{S C}$ will be very close to those inserted in the INT1.

TABLE II

Parameters of the Prototype

\begin{tabular}{cc}
\hline Nominal rms grid voltage & $V_{s}=127 \mathrm{~V}$ \\
\hline Nominal utility frequency & $f=60 \mathrm{~Hz}$ \\
\hline DC-Bus average voltage & $V_{D C}=220 \mathrm{~V}$ \\
\hline DC-Bus capacitance & $C_{D C}=705 \mu \mathrm{F}$ \\
\hline Inductance $L_{f}$ (full-bridge inverter) & $L_{f}=5.07 \mathrm{mH}$ \\
\hline Internal resistance of $L_{f}$ & $R_{L f}=0.2 \Omega$ \\
\hline Output impedance of the PV array in STC & $R_{p v}=3.87 \Omega$ \\
\hline$C_{1}$ Capacitor (quadratic boost converter) & $C_{I}=990 \mu \mathrm{F}$ \\
\hline Specified average voltage of the $\mathrm{C}_{2}$ capacitor & $V_{C 2}=81.5 \mathrm{~V}$ \\
\hline$C_{2}$ Capacitor (quadratic boost converter) & $C_{2}=990 \mu \mathrm{F}$ \\
\hline Specified average current of the inductor $L_{1}$ & $I_{L I}=7.67 \mathrm{~A}$ \\
\hline Inductance $L_{I}$ (quadratic boost converter) & $L_{I}=1.5 \mathrm{mH}$ \\
\hline Internal resistance of $L_{1}$ & $R_{L I}=0.18 \Omega$ \\
\hline Inductance $L_{2}$ (quadratic boost converter) & $L_{2}=2.11 \mathrm{mH}$ \\
\hline Internal resistance of $L_{2}$ & $R_{L 2}=0.2 \Omega$ \\
\hline Duty cycle of the quadratic boost converter & $D=0.62$ \\
\hline PWM converter switching frequencies & $f_{S w}=20 \mathrm{kHz}$ \\
\hline Sampling frequency of the P\&O MPPT & $f_{S M P P T}=5 \mathrm{~Hz}$ \\
\hline P\&O voltage step size & $\Delta v=0.5 \mathrm{~V}$ \\
\hline DSC Sampling frequency & $f_{S D S C}=60 \mathrm{kHz}$ \\
\hline DAQ sampling frequency & $f_{S} D A Q=5 \mathrm{kHz}$ \\
\hline
\end{tabular}

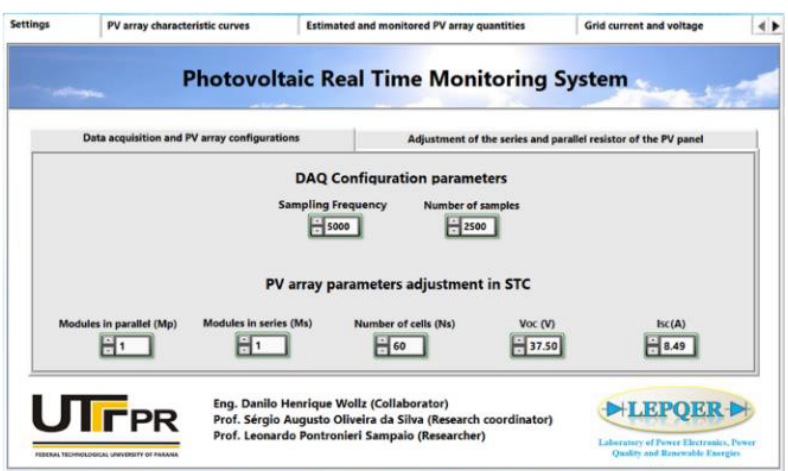

(a)

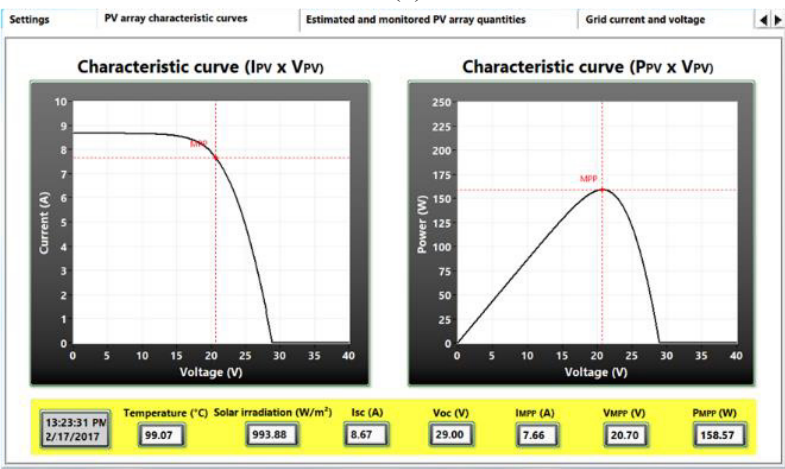

(c)
Figure 8c (INT3) presents the third interface, called "PV array characteristic curves". In the INT3, the curves $I_{P V} \times V_{P V}$ and $P_{P V} \times V_{P V}$ are plotted. They are obtained from the real information (measured values) of the solar irradiation and temperature on the PV array. With these curves, the user can observe the estimated values of the voltage $\left(V_{M P P}\right)$ and current $\left(I_{M P P}\right)$ of the PV array, referring to the estimated maximum power point $\left(P_{M P P}\right)$. It is worth mentioning that the estimated values achieved with the PV model are obtained using the measured real values of solar irradiation and temperature.

TABLE III

Design Specifications and Gains of the Controllers

\begin{tabular}{cc}
\hline PWM Gain & $K_{P W M}=5.33 \times 10^{-4}$ \\
\hline $\mathrm{PI}_{i}$ controller Gains & $K_{P i}=728,17 ;$ \\
(Full-bridge inverter current-loop) & $K_{I i}=4822997.72$ \\
\hline $\mathrm{PI}_{i}$ Crossover frequency & $\omega_{c i}=17951.95 \mathrm{rad} / \mathrm{s}$ \\
\hline $\mathrm{PI}_{i}$ Phase margin & $P M_{i}=67^{\circ}$ \\
\hline $\mathrm{PI}_{v}$ controller Gains & $K_{P v}=0.07138 ;$ \\
$\left(\mathrm{DC}-\right.$ bus voltage loop) $I_{v}=0.395$ \\
\hline $\mathrm{PI}_{v}$ Crossover frequency & $\omega_{c v}=31.42 \mathrm{rad} / \mathrm{s}$ \\
\hline $\mathrm{PI}_{v}$ Phase margin & $P M_{v}=87^{\circ}$ \\
\hline $\mathrm{PI}_{p l l}$ controller Gains & $k_{P p l l}=424.3 ;$ \\
$($ PLL system) & $k_{I p l l}=32234$ \\
\hline $\mathrm{PI}_{p l l}$ Crossover frequency & $\omega_{c p l l}=430.874 \mathrm{rad} / \mathrm{s}$ \\
\hline $\mathrm{PI}_{p l l}$ Phase margin & $P M_{p l l}=80^{\circ}$ \\
\hline $\mathrm{PI}_{i b}$ controller Gains & $K_{P i b}=130.33 ;$ \\
\hline Inner-loop of the DC-DC converter) $_{i b}$ Crossover frequency & $K_{I i b}=17829.96$ \\
\hline $\mathrm{PI}_{i b}$ Phase margin & $\omega_{c i b}=62831.85 \mathrm{rad} / \mathrm{s}$ \\
\hline $\mathrm{PI}_{v b}$ controller Gains & $P M_{i b}=65^{\circ}$ \\
\hline $\mathrm{PI}_{v b}$ Crossover frequency & $K_{P v b}=0.0818 ;$ \\
$\mathrm{PI}_{v b}$ Phase margin & $K_{I v b}=27.36$ \\
\hline & $\omega_{c v b}=96.66 \mathrm{rad} / \mathrm{s}$ \\
\hline Outer-loop of the DC-DC converter) & $P M_{v b}=80^{\circ}$ \\
\hline
\end{tabular}

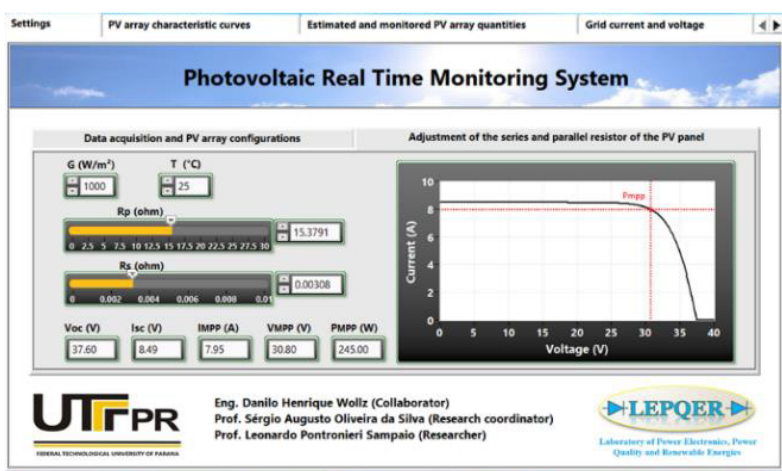

(b)

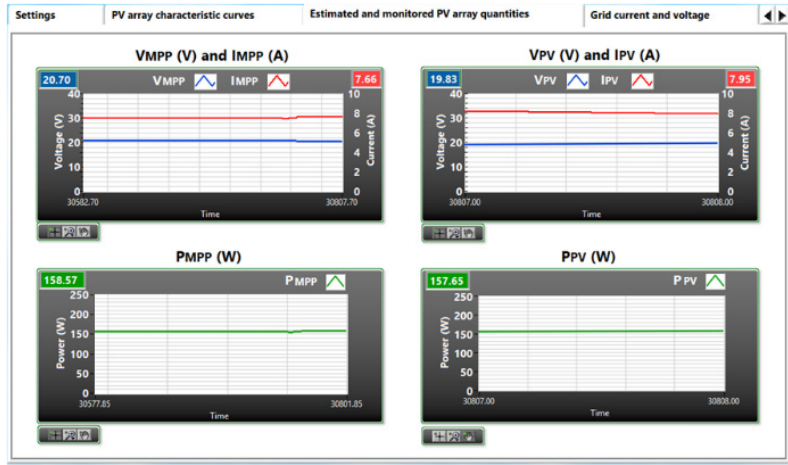

(d)

Fig. 8. Graphical user interface of the RTMS: (a) configurations, (b) adjustments of the series and parallel resistances of the PV cell model, (c) characteristic curves of the photovoltaic array, (d) estimated and monitored quantities of the photovoltaic array. 


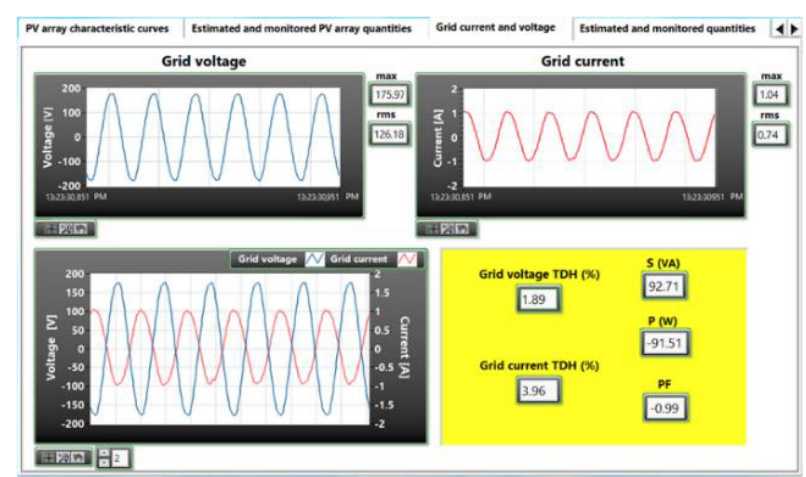

(a)

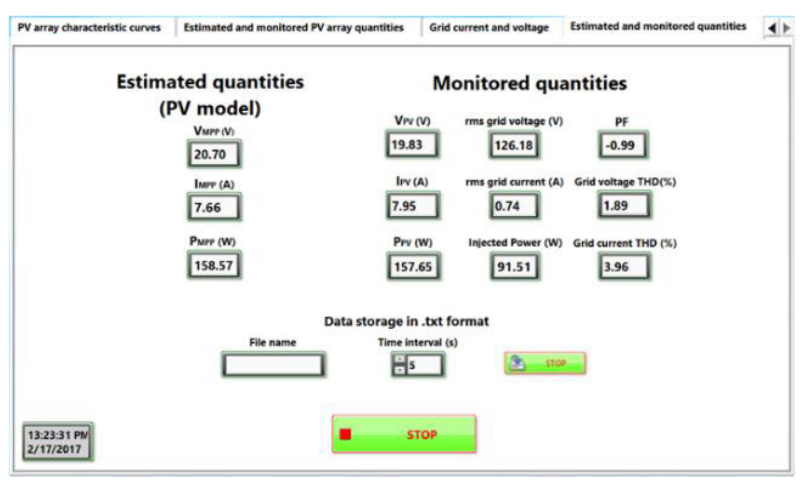

(b)

Fig. 9. Graphical user interface of the RTMS: (a) monitored quantities of the voltage and current injected into the grid, (b) estimated and monitored quantities.

Figure 8d shows the INT4, called "Estimated and monitored PV array quantities". In this interface, the curves referring to the values of the monitored quantities $V_{P V}, I_{P V}$ and $P_{P V}$ are plotted, as well as the quantities estimated by the model, $V_{M P P}, I_{M P P}$ and $P_{M P P}$. Thus, the user can check if the power produced by the PV panel is compatible with the estimated PV power, such that the performance of the MPPT algorithm can be verified.

Figure 9a shows the interface 5 (INT5), called "Grid current and voltage". This window allows the user to see the waveforms of the grid voltage $\left(v_{S}\right)$ and the current injected into the grid $\left(i_{S}\right)$. Also, the THD of both the voltage $v_{S}$ and the current $i_{S}$ can be analyzed. In addition, the grid apparent (S) power and active power $(\mathrm{P})$ injected into the grid, as well as the PF can also be calculated.

Finally, Figure 9b shows the INT6, called "Estimated and monitored quantities". This window allows the user to see the values of all estimated and monitored magnitudes of the system. Moreover, the INT6 provides the option of storing the data obtained in a configurable time interval. The data is stored in ".txt" format, which makes it easy to use such data in other text editing programs for reporting purposes.

The efficiency of the proposed system could be achieved experimentally by comparing the results obtained using the RTMS with those obtained from the Wattmeter Y-WT3000 for the assessment of VPV, IPV, PPV, Vs (rms grid voltage) Is (rms current injected into the grid), $\mathrm{P}$ (Active Power) and PF (Power Factor). To measure the current THD, the power quality analyzer FLUKE F-43B was used. The curves of the following magnitudes $V_{P V}, I_{P V}, P_{P V}, v_{S}$ and $i_{S}$ obtained through the Wattmeter Y-WT3000 are shown in Figure 10.

All the experimental results are summarized in Table IV. Besides being an important educational tool, based on the analysis of the obtained results, the RTMS demonstrated remarkable effectiveness.

\section{EDUCATIONAL METHODOLOGY BY USING THE DIDACTIC WORKBENCH}

This section presents the didactic methodology and results obtained from the use of the didactic workbench shown in Figure 11. The methodology was applied to the discipline called Photovoltaic Systems, taught in both master and doctoral courses inserted in the post-graduation program in electrical engineering of UTFPR-CP, whose discipline codes are addressed as ET51K and EW43G, respectively.

The presented approach was developed through six students regularly enrolled on the course, which was given in the first semester of 2017. To carry out the classes in the laboratory, beyond to the didactic workbench, the following equipment was used: 1) computer with Maltab ${ }^{\circledR}$ software; 2) digital oscilloscope with four isolated channels (Tektronix); 3) power quality analyzer (Fluke - 43B), 4) Wattmeter (Yokogawa-WT3000), and 5) multimeters.

The students participated individually in the practical classes using the didactic workbench, where they were motivated to confront and analyze the results obtained in the experimental tests with those obtained by means of computational simulations.

After the practical activities, the students were asked about the main ease and/or difficulties they encountered during the lessons, as well as what they considered to be the added value (advance) in the learning of the contents directed to PV systems through the use of the didactic workbench.

Finally, anonymously, the students completed a form intended to evaluate the didactic workbench and the methodology used during the experimental class.

Table $\mathrm{V}$ presents the mean and standard deviation of the responses presented by the students according to the proposed activities (PA) using the didactic workbench in the practical classes.

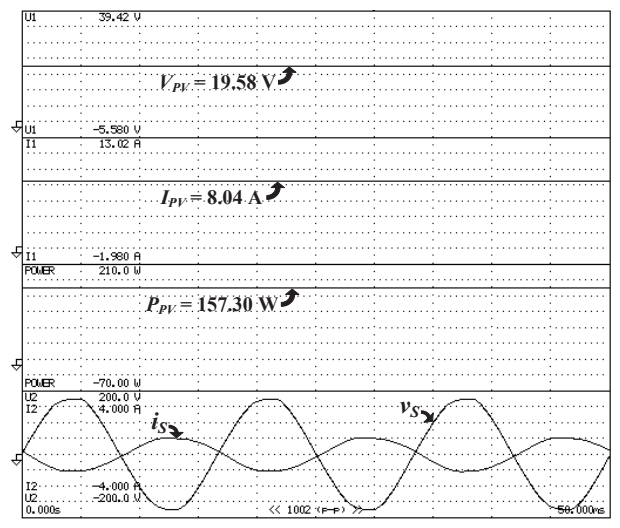

Fig. 10. Experimental results - Y-WT3000 (5s/div): PV voltage $\left(V_{P V}\right),(4.75 \mathrm{~V} / \mathrm{div}) ; \mathrm{PV}$ current $\left(I_{P V}\right),(1.875 \mathrm{~A} / \mathrm{div}) ; \mathrm{PV}$ power $\left(P_{P V}\right)$, $(35 \mathrm{~W} / \mathrm{div})$; grid voltage $(v s),(50 \mathrm{~V} / \mathrm{div})$; grid current $(i s),(1 \mathrm{~A} / \mathrm{div})$. 


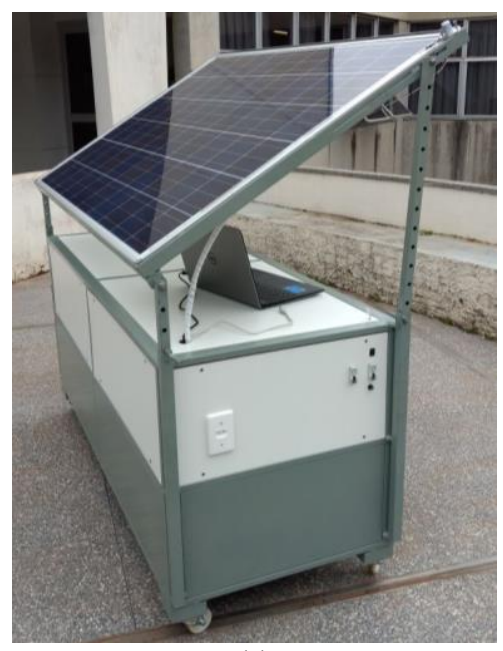

(a)

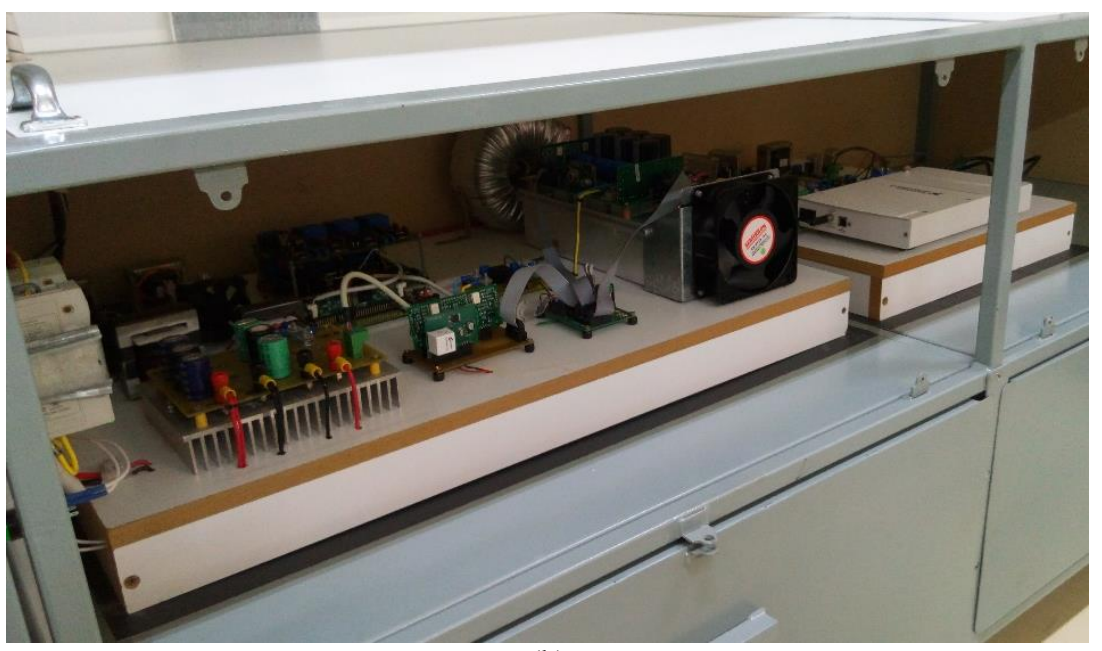

(b)

Fig. 11. Experimental configuration of the didactic workbench: (a) overview of the didactic workbench; (b) organization and assembly of the power converters, signal conditioning boards, digital signal controller, and among others experimental hardware.

TABLE IV

Comparison Between Estimated and Experimental Results

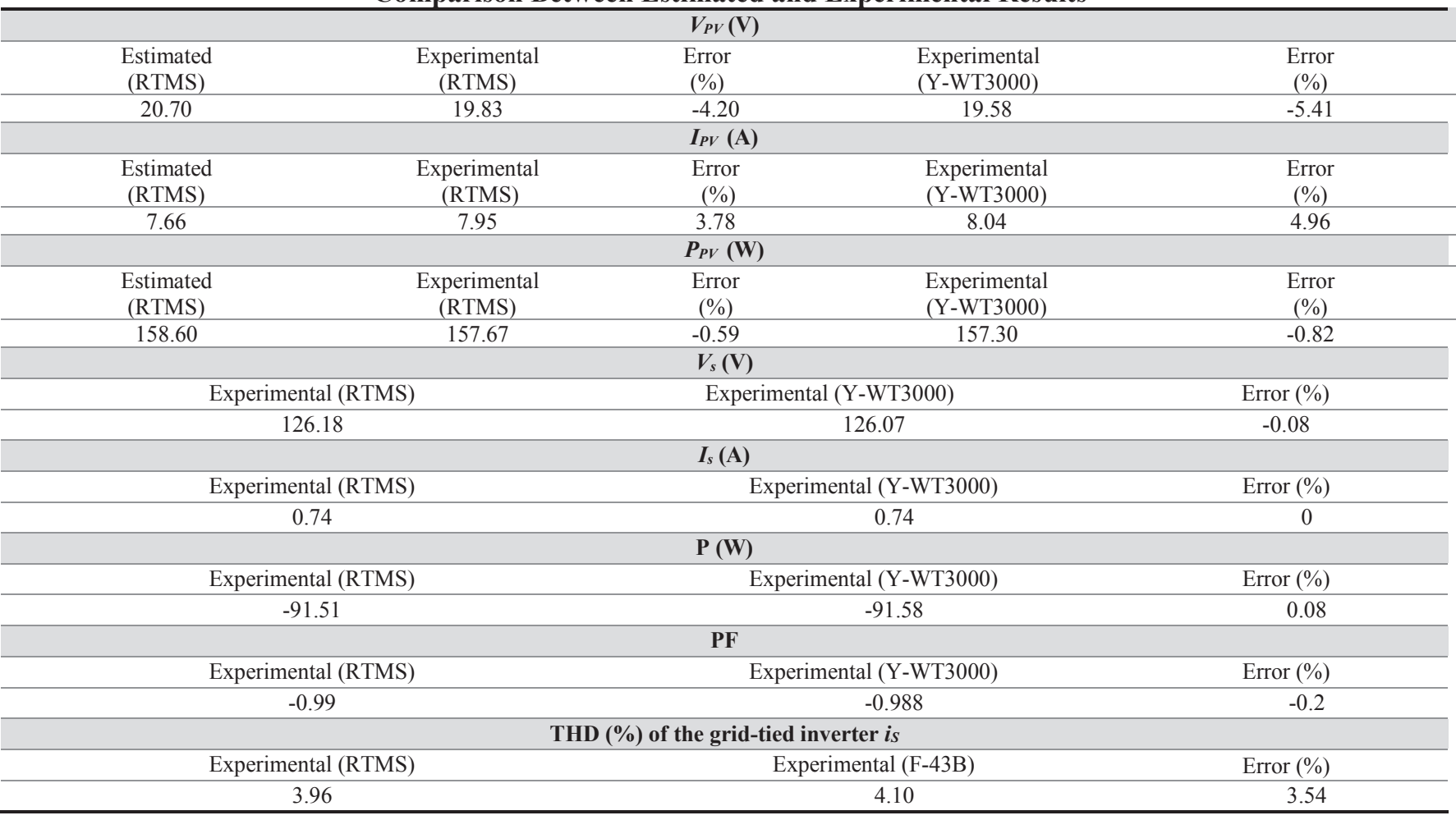

The proposed activities are described as follows:

- $\quad$ PA1 - From the mathematical equations (1) to (6) of the PV cell model, determine the series resistance $R_{S}$ of the PV model, ignoring the parallel resistance $R_{p}$;

- $\quad$ PA2 - Determine, in an interactive way, the values of the resistances $R_{s}$ and $R_{p}$ used in the mathematical PV cell model through the graphical interface of the Real Time Monitoring System (RTMS), which is integrated with the didactic workbench;

- PA3 - Record the values of solar irradiance and temperature obtained in the RTMS. From the values obtained, draw the characteristic curves of the PV panel
$\left(P_{P V} \times V_{P V}\right.$ and $\left.I_{P V} \times V_{P V}\right)$. After that, compare the values of voltage, current, and power at the maximum power point (MPP) obtained both by simulation and experimentally using the RTMS;

- PA4 - Considering the DC/DC Boost converter together with the MPPT P\&O-based algorithm implemented in the system, verify the behavior of the PV system for different conditions of step increments in voltage used in the MPPT algorithm. According to the recorded values of solar irradiation and temperature, evaluate by means of the theoretical curves (Matlab ${ }^{\circledR}$ software) whether the PV system is operating in the region of the MPP; 
TABLE V

Mean and Standard Deviation Responses Presented by the Students According to the Proposed Activities Using the Didactic Workbench in Experimental Class

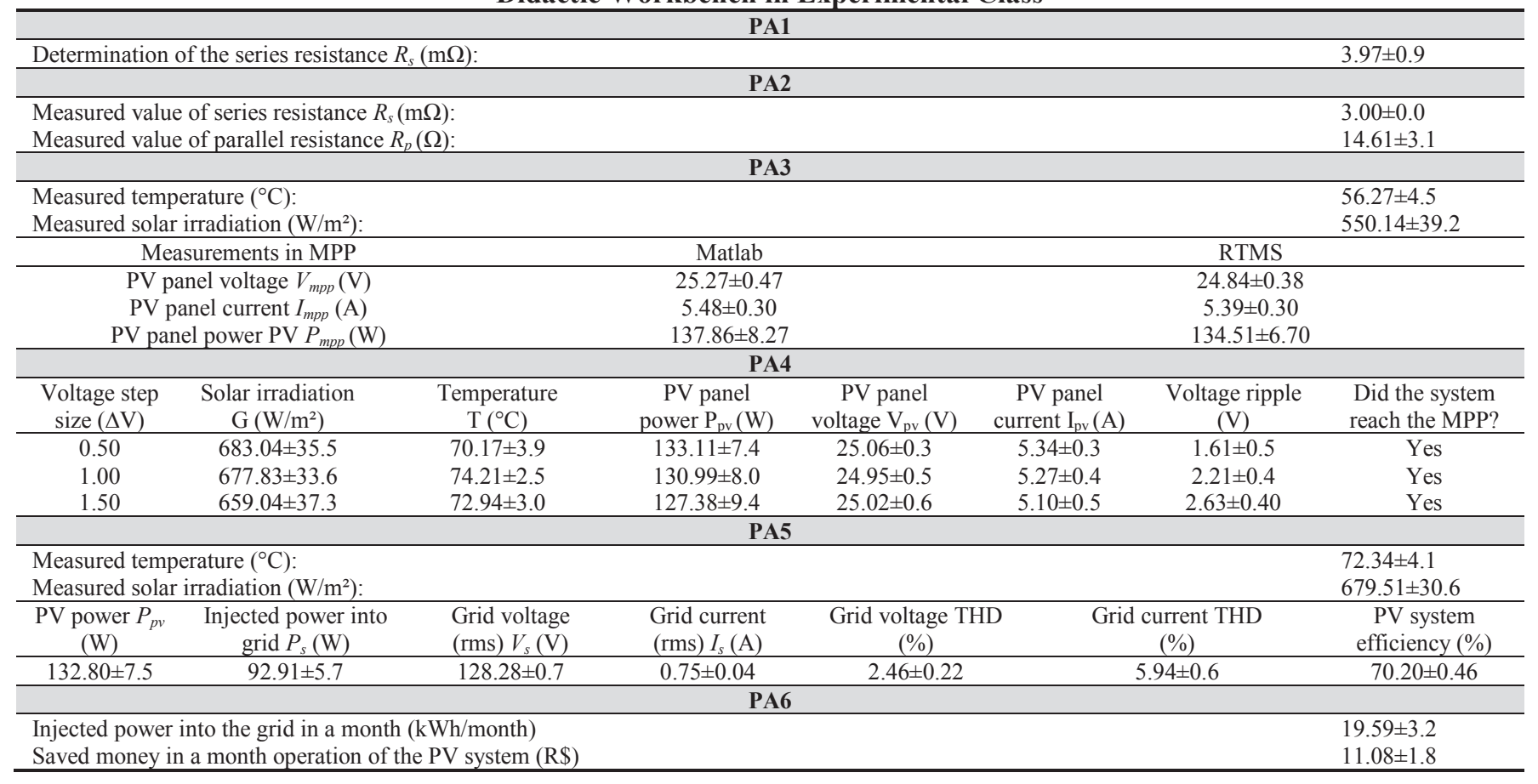

- $\quad$ PA5 - Considering that all the energy extracted from the PV panel is supplied to the grid, observe the voltages and currents of the PV array and power grid. With the values recorded, determine the efficiency of the system and analyze the quality of the current injected into the power grid;

- PA6 - Considering that the PV system under study is installed in a residence with average consumption of 70 $\mathrm{kW} /$ month, calculate the power injected during the month, as well as the energy saving. Consider a mean solar irradiance of $70 \%$ during 8 hours of system operation per day, and a tariff cost of electric energy of $\mathrm{R} \$ 0.57 \mathrm{kWh} /$ month.

Table VI presents the items used in the evaluation of the educational methodology addressed during the development of the experimental activities with the use of the didactic workbench for teaching concepts of PV systems. For each question presented, the student was required to mark his/her evaluation considering one of the four available options, as follows: A) strongly agree (100\%); B) partially agree (50\%), C) agree in part (25\%); and D) strongly disagree $(0 \%)$.

Based on the list of questions presented in Table VI, the evaluations of the information collected from the didactic workbench, as well as the educational methodology, were analyzed. The results of this evaluation are presented as a bar chart shown in Figure 12.

The analysis was performed taking into account the calculation of the mean of each question answered by the students, according to the choice of weights given to items A, $\mathrm{B}, \mathrm{C}$, and D.

\section{TABLE VI}

Questionnaire Submitted to the Students to Evaluate the Didactic Workbench and the Methodology Used in the Experimental Classes

\begin{tabular}{cl}
\hline $\mathbf{N}$ & \multicolumn{1}{c}{ Questions } \\
\hline 1 & $\begin{array}{l}\text { Does the real-time monitoring system (RTMS) help the } \\
\text { understanding and comprehension of the topics covered in the } \\
\text { discipline of Photovoltaic Systems (PVS)? }\end{array}$ \\
\hline 2 & $\begin{array}{l}\text { Does the RTMS employed motivate the student to become interested } \\
\text { in the discipline? }\end{array}$ \\
\hline 3 & $\begin{array}{l}\text { Do the RTMS and PAs stimulate student interest in photovoltaic } \\
\text { systems? }\end{array}$ \\
\hline 4 & Is the RTMS easy to use? \\
\hline 5 & Were the RTMS and PAs presented clearly and effectively? \\
\hline 6 & $\begin{array}{l}\text { Do the RTMS and PAs aid in the comprehension and practical } \\
\text { accompaniment of Photovoltaic Systems in the laboratory? }\end{array}$ \\
\hline 7 & $\begin{array}{l}\text { Does the use of RTMS contribute to the verification and behavior of } \\
\text { the PV array both in practice and in simulation? }\end{array}$ \\
\hline 8 & Was the usefulness of the discipline greater when using the RTMS? \\
\hline 9 & $\begin{array}{l}\text { Do the contents covered using the RTMS comply with the content of } \\
\text { the discipline of Photovoltaic Systems? }\end{array}$ \\
\hline
\end{tabular}

In general, the students perceived a better understanding regarding themes associated with photovoltaic systems. In addition, students improved their critical analysis skills after performing practical activities and demonstrated advances in understanding the topics covered in the course. During the practical classes, it was possible to observe greater involvement and participation of the students in the proposed activities. Finally, it was observed that the students presented greater motivation both during and after the accomplishment of these activities, demonstrating greater commitment to the study of the discipline, as well as enthusiasm in the discussion of themes related to topics involving PV systems. 


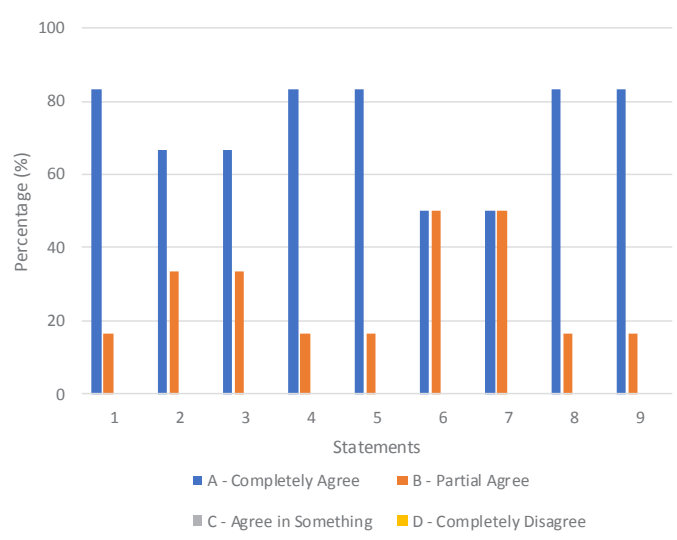

Fig. 12. Survey results applied to the students taking into account the use of didactic workbench in experimental class.

\section{CONCLUSION}

This work presented a didactic workbench, indicated to assist the teaching of PV systems addressed in topics/subjects of undergraduate and postgraduate electrical engineering courses. The system consists of a real-time monitoring system operating in conjunction with a double-stage PV system connected to the utility grid. In addition, effective and dynamic interaction with the students was supported by means of an accessible graphical user interface.

By means of a mathematical model that allows to simulate a photovoltaic cell, it was possible to compare computationally and experimentally the performance of the PV system in real-time. Thus, the proposed educational platform can also be used to assist student in projects tied to MPPT techniques.

The effectiveness of the proposed didactic workbench was evaluated in an educational environment, where it was proved to be a promising and versatile tool when applied to teaching of photovoltaic systems.

\section{ACKNOWLEDGEMENTS}

The authors acknowledge the financial support received from Pesqueiro Energia S/A.

\section{REFERENCES}

[1] S. A. O. da Silva, L. P. Sampaio, F. M. Oliveira, F. R. Durand, "Feed-Forward DC-Bus Control Loop Applied to a Single-Phase Grid-Connected PV System Operating with PSO-Based MPPT Technique and Active PowerLine Conditioning", IET Renewable Power Generation, vol. 11, nº 1, pp. 183-193, Jan. 2017.

[2] H. Abu-Rub, M. Malinowski, K. Al-Haddad, Challenges of the Current Energy Scenario: The Power Electronics Contribution, Power Electronics for Renewable Energy Systems, Transportation and Industrial Applications, Wiley-IEEE Press, 2014.

[3] M. A. G. Brito, L. P. Sampaio, G. A. Melo, C. A. Canesin, "Inversor Buck-boost Tri-state Integrado Trifásico para Aplicações Fotovoltáicas", Eletrônica de Potência - SOBRAEP, vol. 19, $\mathrm{n}^{\mathrm{o}}$ 1, pp. 81-89, Feb. 2014.
[4] E. Sáiz-Marín, E. Lobato, I. Egido, "New Challenges to Wind Energy Voltage Control. Survey of Recent Practice and Literature Review", IET Renewable Power Generation, vol. 12, nº 3, pp. 267-278, Feb. 2018.

[5] L. S. Barros, C. M. V. Barros, "Modificação no Controle do Lado da Rede de Geradores Eólicos Baseados em PMSG para Ampliar a Suportabilidade a Afundamentos de Tensão", Eletrônica de Potência - SOBRAEP, vol. 22, $\mathrm{n}^{\mathrm{o}} 2$, June 2017.

[6] Z. Abdmouleh, A. Gastli, L. Ben-Brahim, M. Haouari, N. A. Al-Emadi, "Review of Optimization Techniques Applied for the Integration of Distributed Generation from Renewable Energy Sources", Renewable Energy, vol. 113, pp. 266-280, Dec. 2017.

[7] F. Blaabjerg, Y. Yang, D. Yang, X. Wang, "Distributed Power-Generation Systems and Protection", Proceedings of the IEEE, vol. 105, n 7, pp. 1311-1331, July 2017.

[8] A. Merabet, Md. A. Islam, R. Beguenane, A. M. Trzynadlowski, "Multivariable Control Algorithm for Laboratory Experiments in Wind Energy Conversion", Renewable Energy, vol. 83, pp. 162-170, Nov. 2015.

[9] J. A. Pomilio, C. A. Canesin, F. L. M. Antunes, F. S. dos Reis, L. P. Sampaio, "Power Electronics Courses for the New Paradigms of the Electrical System", in Proc. of COBEP, pp. 1027-1031, 2011.

[10] D. Srinivasan, "Teaching sustainable Energy Course Through Real World Case Studies, Projects and Simulations", in Proc. of IEEE International Conference on Teaching, Assessment, and Learning for Engineering, pp. 436-440, 2016.

[11] G. P. Landi, F. A. S. Gonçalves, F. P. Marafão, H. K. M. Paredes, "Interactive android application for education in AC-to-DC converters", in Proc. of COBEP, pp. 1-5, 2017.

[12] C. A. Canesin, F. A. S. Gonçalves, L. P. Sampaio, "Simulation Tools for Power Electronics Courses Based on Java Technologies", IEEE Transactions on Education, vol. 13, n 2, pp. 91-98, Nov. 2010.

[13] L. P. Sampaio, S. A. O. Silva, A. N. Vargas, "Desenvolvimento de uma Plataforma Computacional Gráfica Dedicada ao Ensino De Sistemas Fotovoltaicos usando um Emulador Eletrônico", Eletrônica de Potência-SOBRAEP, vol. 22, nº 1, pp. 91-101, March 2017.

[14] L. P. Sampaio, M. A. G. de Brito, G. A. e Melo, C. A. Canesin, "Computer tools to aid the learning and design steps for photovoltaic systems", in Proc. of COBEP, pp. 1021-1026, 2011.

[15] C. Goldemberg, E. L. Pellini, W. Kaiser, W. Komatsu, "A Python Based Power Electronics E-learning Tool", in Proc. of COBEP, pp. 1088-1092, 2009.

[16] A. Pérez-Santiago, M. Reyes-Carrasquillo, E. I. OrtizRivera, "Work in Progress-HOMER: An Educational Tool to Learn About the Design of Renewable Energy Systems at the Undergraduate Level", in Proc. of Frontiers in Education Conference Proceedings, pp. 16, 2012.

[17] F. Martinez, L. C. Herrero, S. de Pablo, "Project-Based Learning and Rubrics in the Teaching of Power Supplies 
and Photovoltaic Electricity", IEEE Transactions on Education, vol. 54, no 1, pp. 87-96, Feb. 2011.

[18] G. Verbič, C. Keerthisinghe, A. C. Chapman, "A ProjectBased Cooperative Approach to Teaching Sustainable Energy Systems", IEEE Transactions on Education, vol. 60, n⿳3 3, pp. 221-228, Aug. 2017.

[19] R. C. Garcia, B. S. Heck, "Enhancing classical controls education via interactive GUI design", IEEE Control Systems, vol. 19, no 3, pp. 77-82, June 1999.

[20] R. W. Erickson, D. Maksimovic, Fundamentals of Power Electronics, Springer, USA, 2001.

[21] S. Lui, R. A. Dougal, "Dynamic Multiphysics Model for Solar Array", IEEE Transactions on Energy Conversion, vol. 17, no 2, pp. 285-294, June 2002.

[22] M. M. Casaro, D. C. Martins, "Modelo de Arranjo Fotovoltaico Destinado a Análises em Eletrônica de Potência via Simulação", Eletrônica de Potência SOBRAEP, vol. 13, no 3, pp. 141-146, Ago. 2008.

[23] S. A. Rahman, R. K.Varma, T. Vanderheide, "Generalised Model of a Photovoltaic Panel", IET Renewable Power Generation, vol. 8, n 3 pp. 217-229, March 2014.

[24] D. Barater, G. Buticchi, E. Lorenzani, C. Concari, "Active Common-Mode Filter for Ground Leakage Current Reduction in Grid-Connected PV Converters Operating with Arbitrary Power Factor", IEEE Transactions on Industrial Electronics, vol. 61, nº 8, pp. 3940-3950, Aug. 2014.

[25] B. A. Angélico, L. B. G. Campanhol, S. A. O. Silva, "Proportional-Integral/Proportional-Integral-Derivative Tuning Procedure of a Single-Phase Shunt Active Power Filter Using Bode Diagram", IET Power Electronics, vol. 7, n 10, pp. 2647-2659, Aug. 2014.

[26] V. D. Bacon, S. A. O. Silva, L. B. G. Campanhol, B. A. Angélico, "Stability Analysis and Performance Evaluation of a Single-Phase Phase-Locked Loop Algorithm Using a Non-Autonomous Adaptive Filter", IET Power Electronics, vol. 7, nº 8, pp. 2081-2092, Aug. 2014.

[27] M. A. G. de Brito, L. P. Sampaio, G. A. Melo, C. A. Canesin, "Contribuição ao Estudo dos Principais Algoritmos de Extração da Máxima Potência dos Painéis Fotovoltaicos", Eletrônica de Potência - SOBRAEP, vol. 17, n 3, pp. 592-600, Ago. 2012.

\section{BIOGRAPHIES}

Sérgio Augusto Oliveira da Silva, was born in Joaquim Távora, Brazil, in 1964. He received the B.S. and M.S. degrees in electrical engineering from Federal University of Santa Catarina (UFSC), Florianopolis, SC, Brazil, in 1987 and 1989, respectively. He received Ph.D. degree from Federal University of Minas Gerais (UFMG), Belo Horizonte, MG, Brazil, in 2001. Since 1993, he has been with the Electrical Engineering Department of Federal University of Technology (UTFPR-CP), Cornélio Procópio, PR, Brazil, where he is currently a full Professor of Electrical Engineering and coordinator of the Laboratory of Power Electronics, Power Quality and Renewable Energies (LEPQER). His research interests are related to power electronics applications involving UPS systems, active power-line filters, photovoltaic systems, control systems, power quality and educational tool for power electronics teaching. He is member of Brazilian Power Electronics Society and IEEE Industrial Electronics Society.

Danilo Henrique Wollz, was born in Siqueira Campos, Brazil, in 1991. He received the B.Sc. degree in electrical engineering from the Federal University of Technology Paraná, Campus of Cornélio Procópio (UTFPR-CP) in 2016. Currently, he is a student of the Master Science course in electrical engineering at Federal University of TechnologyParaná (UTFPR-CP). He is a member of the Laboratory of Power Electronics, Power Quality and Renewable Energies (LEPQER). His interests include renewable energy systems, power quality, active power filters and educational tools applied in power electronics teaching. He is a member of Brazilian Power Electronics Society.

Leonardo Poltronieri Sampaio, was born in São José do Rio Preto, SP, Brazil, in 1983. He received the B.Sc., M.Sc. and $\mathrm{Ph} . \mathrm{D}$. degrees in electrical engineering from the São Paulo State University, Ilha Solteira, Brazil, in 2008, 2010 and 2013, respectively. Since 2012, he has been Professor at Federal University of Technology, Cornélio Procópio, Brazil. He is member of the Laboratory of Power Electronics, Power Quality and Renewable Energies (LEPQER). His interests include computer programming, education in power electronics, education tools, DC-DC converters, inverters, renewable and alternative energy source, photovoltaic systems, power electronic converters. He is a member of Brazilian Power Electronics Society. 